\title{
Biomarkers as Predictors for Conversion from Mild Cognitive Impairment to Alzheimer-Type Dementia: Implications for Trial Design
}

Citation for published version (APA):

van Rossum, I. A., Vos, S., Handels, R., \& Visser, P. J. (2010). Biomarkers as Predictors for Conversion from Mild Cognitive Impairment to Alzheimer-Type Dementia: Implications for Trial Design. Journal of Alzheimer's Disease, 20(3), 881-891. https://doi.org/10.3233/JAD-2010-091606

Document status and date:

Published: 01/01/2010

DOI:

10.3233/JAD-2010-091606

Document Version:

Publisher's PDF, also known as Version of record

Document license:

Taverne

Please check the document version of this publication:

- A submitted manuscript is the version of the article upon submission and before peer-review. There can be important differences between the submitted version and the official published version of record.

People interested in the research are advised to contact the author for the final version of the publication, or visit the DOI to the publisher's website.

- The final author version and the galley proof are versions of the publication after peer review.

- The final published version features the final layout of the paper including the volume, issue and page numbers.

Link to publication

\footnotetext{
General rights rights.

- You may freely distribute the URL identifying the publication in the public portal. please follow below link for the End User Agreement:

www.umlib.nl/taverne-license

Take down policy

If you believe that this document breaches copyright please contact us at:

repository@maastrichtuniversity.nl

providing details and we will investigate your claim.
}

Copyright and moral rights for the publications made accessible in the public portal are retained by the authors and/or other copyright owners and it is a condition of accessing publications that users recognise and abide by the legal requirements associated with these

- Users may download and print one copy of any publication from the public portal for the purpose of private study or research.

- You may not further distribute the material or use it for any profit-making activity or commercial gain

If the publication is distributed under the terms of Article $25 \mathrm{fa}$ of the Dutch Copyright Act, indicated by the "Taverne" license above, 


\title{
Biomarkers as Predictors for Conversion from Mild Cognitive Impairment to Alzheimer-Type Dementia: Implications for Trial Design
}

\author{
Ineke A. van Rossum ${ }^{\mathrm{a}}$, Stephanie Vos ${ }^{\mathrm{b}}$, Ron Handels ${ }^{\mathrm{b}}$ and Pieter Jelle Visser ${ }^{\mathrm{a}, \mathrm{b}, *}$ \\ ${ }^{a}$ Alzheimer Centre, Department of Neurology, VU University Medical Centre, Amsterdam, The Netherlands \\ ${ }^{\mathrm{b}}$ Alzheimer Centre, School for Mental Health and Neuroscience (MHeNS), University Medical Centre, Maastricht, \\ The Netherlands
}

Accepted 9 February 2010

\begin{abstract}
Disease modifying drugs for Alzheimer's disease (AD) are likely to be most effective when given in non-demented subjects. In this review we summarized biomarkers in cerebrospinal fluid (CSF) and blood that can predict AD-type dementia in subjects with mild cognitive impairment (MCI). In addition, we investigated whether these markers could reduce sample size and costs if used to select subjects for trials on the prevention of AD in subjects with MCI. A meta-analysis of markers that had been investigated in multiple studies showed that the combination of amyloid- $\beta(\mathrm{A} \beta)_{1-42}$ and tau in CSF had the best predictive accuracy for $\mathrm{AD}$ (odds ratio (OR) 18.1, 95\% confidence interval (CI) 9.6-32.4). A $\beta_{1-42}$, total tau, and phosphorylated tau in CSF also predicted conversion, but with lower accuracy (OR 7.5 to 8.1). Plasma levels of $\mathrm{A} \beta_{1-40}, \mathrm{~A} \beta_{1-42}$, the ratio $\mathrm{A} \beta_{1-42} / \mathrm{A} \beta_{1-40}$ and homocysteine did not predict outcome. In a fictive trial design, the use of the combination of $\mathrm{A} \beta_{1-42}$ and tau in CSF in the selection of subjects could reduce sample size by $67 \%$ and trial costs by $60 \%$ compared to a trial in which unselected subjects with MCI would be enrolled. In conclusion, the combination of $\mathrm{A} \beta_{1-42}$ and tau in CSF is useful to select subjects for trials that aim to slow down the progression from MCI to AD-type dementia.
\end{abstract}

Keywords: Alzheimer's disease, biomarkers, blood, cerebrospinal fluid, cost-benefit, decision analysis, mild cognitive impairment

\section{INTRODUCTION}

Disease modifying drugs that may slow down the progression of Alzheimer's disease (AD) are currently under development. These drugs are likely to be most effective when given early in the course of the disease, but diagnostic criteria for $\mathrm{AD}$ in non-demented sub-

*Correspondence to: Pieter Jelle Visser, Department of Psychiatry, Maastricht University, Medical Centre, PO Box 616, 6200 MD Maastricht, The Netherlands. Tel.: +31 6306166 79; Fax: +31 842 134 161; E-mail: pj.visser@np.unimaas.nl. jects are presently lacking. Predementia AD cannot be accurately diagnosed by clinical criteria alone, such as criteria for mild cognitive impairment (MCI) [1,2]. Biomarkers may help to increase the diagnostic accuracy compared to clinical criteria [3], because pathological changes of AD can already be found in nondemented subjects [4]. However, which biomarkers would be most useful as inclusion criterion in trials with disease modifying drugs and to what extent these markers could reduce sample size and costs of such trials is unknown.

The aim of the present study was to investigate which 
biomarkers could predict AD-type dementia in subjects with MCI and how the use of these biomarkers as an inclusion criterion for trials with drugs that aim to slow down the progression from MCI to AD-type dementia, could reduce sample size and costs. We limited our study to biomarkers in cerebrospinal fluid (CSF) and blood.

First, we will briefly summarize the pathophysiology in $\mathrm{AD}$, since appropriate biomarkers should reflect $\mathrm{AD}$ pathology [5]. Next, we will discuss biomarkers for the key pathological processes in AD in CSF and blood and discuss their use as predictor for progression to ADtype dementia in subjects with MCI. Of CSF and blood markers that have been investigated in at least four studies, we will calculate pooled measures of predictive accuracy. Finally, we will use the predictive accuracy of the best markers to calculate for a fictive trial how the use of these markers as an inclusion criterion will influence sample size and costs.

\section{PATHOPHYSIOLOGY OF AD}

Abnormalities in amyloid- $\beta(\mathrm{A} \beta)$ processing play a central role in the pathophysiology of $\mathrm{AD}$. In $\mathrm{AD}$, $\mathrm{A} \beta$ peptides aggregate and form oligomers, fibrils, and eventually plaques, a pathological hallmark of AD. Aggregated $\mathrm{A} \beta$ is supposed to be neurotoxic and to initiate a cascade of events including oxidative stress, inflammation, and dysregulation of lipid metabolism. This cascade eventually leads to loss of synapses and cell death, as shown in Fig. 1 [6]. Different isoforms of the $\mathrm{A} \beta$ peptide are generated from the amyloid- $\beta$ protein precursor $(\mathrm{A} \beta \mathrm{PP})$. In $\mathrm{AD}, \mathrm{A} \beta_{1-42}$ seems to be particularly important as it is more prone to aggregate compared to other isoforms. Cumulating evidence suggests that the oligomer form of $\mathrm{A} \beta$ is toxic [7]. The increase in aggregated $\mathrm{A} \beta$ may be caused by either increased production, disturbance of the post-translational modification, or reduced clearance of $\mathrm{A} \beta$. Neurofibrillary tangles are another pathological hallmark of AD. These are aggregates of hyperphosphorylated tau and may contribute to neuronal dysfunction. Inflammatory processes, oxidative stress, and alteration of lipid metabolism are thought to occur as a consequence of $\mathrm{A} \beta$ pathology, but may in turn further dysregulate $\mathrm{A} \beta$ processing. The primary cause for dysregulation of $\mathrm{A} \beta$ metabolism is unknown and multiple factors may be involved, for example genetic or environmental factors.

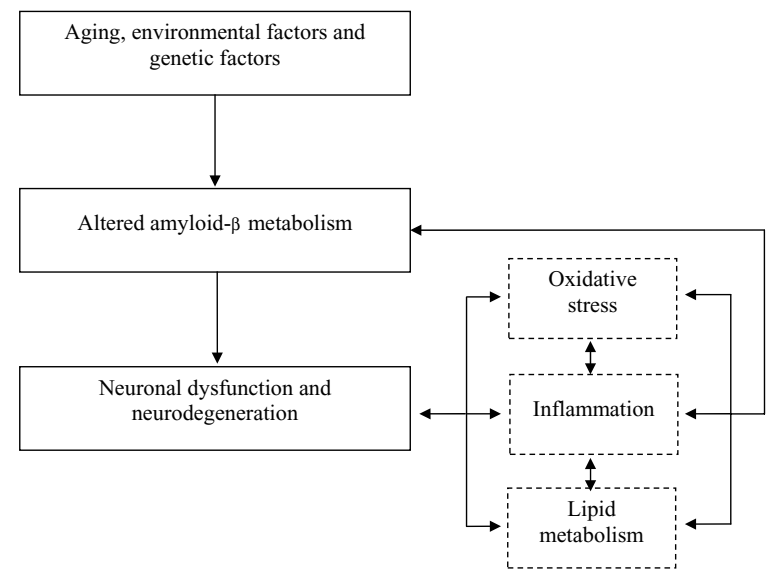

Fig. 1. Pathophysiology of Alzheimer's disease.

\section{BIOMARKERS FOR AD IN SUBJECTS WITH MCI}

Many of the biochemical changes related to the pathophysiology of AD can be measured in vivo in body fluids.

\section{Markers for $A \beta$ processing in CSF}

Biomarkers for $\mathrm{A} \beta$ processing in CSF include isoforms of the peptide itself as well as markers for its production and clearance. $\mathrm{A} \beta$ peptides can be measured with assays that measure monomers or aggregated species, or with assays that are not specific for aggregation status [8-10]. The concentration of $\mathrm{A} \beta_{1-42}$ correlates with the presence of amyloid plaques in the brain [11]. Many studies have shown that in MCI subjects, a low concentration of $\mathrm{A} \beta_{1-42}$ in CSF can predict conversion to AD-type dementia, as will be discussed in more detail below. Also a combination of different $\mathrm{A} \beta$ isoforms in CSF may predict $\mathrm{AD}$-type dementia in subjects with MCI [12]. Production of $\mathrm{A} \beta_{1-42}$ from $\mathrm{A} \beta \mathrm{PP}$ is dependent on the $\beta$-site $\mathrm{A} \beta \mathrm{PP}$ cleaving enzyme (BACE-1). One study showed that increased BACE1 activity could predict AD-type dementia in MCI subjects [13]. Of the peptides that may be involved in the clearance of $\mathrm{A} \beta$ only few have been investigated in CSF of subjects with MCI. Levels of neprilysin were decreased in subjects with progressive MCI and mild AD-type dementia compared to controls [14]. $\mathrm{A} \beta$ binding proteins may also influence $\mathrm{A} \beta$ aggregation and a lower level of serum amyloid $\mathrm{P}$ component predicted AD-type dementia in MCI subjects [15]. 


\section{Markers for A $\beta$ processing in plasma}

In plasma, abnormal $\mathrm{A} \beta$ concentrations have been associated with $\mathrm{AD}$, although they do not correlate with the occurrence of $A \beta$ plaques in the brain $[16,17]$. Four longitudinal studies have assessed predictive value of plasma $\mathrm{A} \beta$ levels in MCI subjects, as will be discussed in more detail below. In a small study, the $\mathrm{A} \beta \mathrm{PP}$ isoform ratio in platelets could predict conversion to ADtype dementia in MCI subjects with a sensitivity and specificity of 0.83 [18].

\section{Markers for neurodegeneration}

Many markers of neurodegeneration are available, but most of them are not specific for AD pathology. Concentrations of total tau (t-tau) and phosphorylated tau ( $\mathrm{p}$-tau) can be measured in CSF and correlate with the presence of neurofibrillary tangles $[11,19]$. In MCI subjects, increased CSF level of t-tau and p-tau were associated with an increased risk of progression to AD-type dementia as will be discussed below. In plasma, levels of tau are very low and no reliable assay is available yet. Other markers for neurodegeneration, like visinin-like protein, neurofilaments, and GAP43 (neuromodulin), are increased in CSF of AD subjects compared to controls [20], but have not been tested as predictor for AD-type dementia in subjects with MCI.

\section{Markers for inflammation}

A wide range of inflammatory markers have been studied in blood and CSF of AD subjects, including cytokines, acute-phase proteins, and complement factors, but none of these markers could discriminate between subjects with AD and healthy controls [21-24]. In MCI, CSF tumor necrosis factor $\alpha$ (TNF- $\alpha$ ) was increased and transforming growth factor $\beta$ (TGF $\beta$ ) was decreased in subjects progressing to AD-type dementia compared to healthy controls, but not compared to subjects with stable MCI [25]. Another study showed higher levels of TNF receptors in CSF as well as in plasma in MCI subjects that converted to AD-type dementia [26,27]. Several other cytokines did not predict progression to AD-type dementia [25,28].

Antibodies against $\mathrm{A} \beta$ are found in CSF and plasma of AD subjects. Studies comparing levels of antibodies of AD subjects and healthy controls showed conflicting results [21]. The possible use of antibodies as marker in MCI has not been studied yet.

\section{Markers for oxidative stress}

Some markers of lipid peroxidation, protein oxidation, and nitrosylation and DNA and RNA oxidation have shown to be abnormal in CSF, plasma, or peripheral blood cells of subjects with AD-type dementia [29]. In MCI subjects, an increased level of F2isoprostane, a marker of lipid peroxidation, was associated with cognitive decline and progression to AD-type dementia [30].

\section{Markers for lipid metabolism}

Serum cholesterol is suggested to be associated with an increased risk for $\mathrm{AD}$, but results have been conflicting [31]. In CSF, increased levels of 24OHC and 27-hydroxycholestrol (27OHC) were found in AD and MCI subjects compared to controls [32-35]. In plasma, results have been conflicting [31]. One study in MCI found that CSF levels of sulfatide and the ratio of sulfatide to phosphatidylinositol were decreased in very mildly demented subjects [36]. However, the predictive accuracy for AD-type dementia in subjects with MCI has not yet been tested.

\section{Other markers}

\section{Homocysteine}

Increased plasma homocysteine may be associated with an increased risk for AD, although the exact pathophysiological mechanism behind this is not clear [37]. Two studies found an association between homocysteine level and incidence of AD in the general population $[38,39]$; another study found no association of plasma homocysteine level and the incidence of MCI [40]. The predictive accuracy of homocysteine for AD-type dementia in subjects with MCI will be discussed in more detail below.

\section{Proteomics}

Unbiased approaches have been useful to select biomarkers in CSF or plasma that may differentiate between AD subjects and healthy controls [23]. In CSF, a panel of 17 proteins and peptides in CSF could distinguish between subjects with stable MCI and subjects with MCI who progressed to AD-type dementia [41]. In plasma, a combination of 18 different proteins in plasma predicted progression to AD-type dementia in MCI subjects with over $90 \%$ accuracy [42]. However, in a subsequent study that tested for reproducibility of these markers, diagnostic accuracy was lower [43]. 
Table 1

Baseline characteristics of studies included in the meta-analysis of CSF biomarkers in subjects with MCI

\begin{tabular}{|c|c|c|c|c|c|c|}
\hline \multirow[t]{2}{*}{ Study } & \multirow[t]{2}{*}{$\mathrm{N}$} & \multirow[t]{2}{*}{ Age } & \multirow[t]{2}{*}{ MMSE } & \multirow[t]{2}{*}{$\begin{array}{c}\text { Follow up } \\
\text { (year) }\end{array}$} & \multicolumn{2}{|c|}{$\begin{array}{c}\text { Markers from each study } \\
\text { included in the meta-analysis* }\end{array}$} \\
\hline & & & & & $\begin{array}{c}\text { Dichotomous } \\
\text { outcome } \\
\text { measure }\end{array}$ & $\begin{array}{c}\text { Cohen's } \\
\text { delta }\end{array}$ \\
\hline Riemenschneider (2002) [59] & 28 & $70.1(8.1)$ & $27.4(1.5)$ & 1.5 & 4 & - \\
\hline Hampel (2003) [50] & 52 & $72.5(8.3)$ & $28.9(1)$ & $0.7(0.4)$ & 1,2 & 1,2 \\
\hline Tarowski (2003) [25] & 56 & $74.0(7.5)$ & $28.6(1.5)$ & 0.8 (range $0.2-3.0$ ) & - & 1,2 \\
\hline Zetterberg (2003) [61] & 53 & range $50-83$ & $27.0(1.7)$ & $1.7(0.8)$ & 2,4 & - \\
\hline Maruyama (2004) [55] & 57 & $73.9(6.2)$ & $25.7(1.3)$ & $2.0(0.4)$ & 2 & 2 \\
\hline Herukka (2005) [53] & 78 & $70.4(7.4)$ & - & 3.0 (range $0.5-12$ ) & $1-4$ & $1,2,3$ \\
\hline Hansson (2006) [52] & 134 & 71.8 (range $50-86$ ) & $27.0(1.6)$ & 4.7 (range $1.1-6.8$ ) & 3,4 & $1,2,3$ \\
\hline Parnetti (2006) [58] & 55 & - & - & 1.0 & $1-3$ & $1,2,3$ \\
\hline Ewers (2007) [47] & 88 & $70.9(7.3)$ & $27.0(2.0)$ & $1.8(0.8)$ & 3 & - \\
\hline Fellgiebel (2007) [48] & 16 & $68.6(7.9)$ & $25.7(2.7)$ & $1.6(0.8)$ & 3 & 2,3 \\
\hline Hansson (2007) [52] & 134 & 71.8 (range $50-86$ ) & $27.1(1.6)$ & 4.7 (range $1.1-6.8$ ) & 1 & - \\
\hline Schonknecht (2007) [60] & 80 & $69.3(7.8)$ & $26.6(1.6)$ & $\geqslant 1$ & - & 2,3 \\
\hline Forsberg (2008) [49] & 21 & $63.3(7.8)$ & $28.2(1.4)$ & $0.7(0.5)$ & $1-3$ & $1,2,3$ \\
\hline Blom (2009) [45] & 58 & $62.9(8.2)$ & - & $4.5(2.4)$ & 4 & $1,2,3$ \\
\hline Brys (2009) [46] & 65 & $71.8(7.9)$ & $27.8(1.8)$ & $2.0(0.6)$ & $2-4$ & 2,3 \\
\hline Kester (2009) [54] & 100 & $67.8(8.2)$ & $26.6(2.4)$ & 1.5 & 1,2 & - \\
\hline Mattsson (2009) [56] & 750 & 69.0 (range 43-89) & $27.0($ range $16-30)$ & 3.0 (range $2-11)$ & $1-4$ & - \\
\hline Papaliagkas (2009) [57] & 53 & $67.7(7.8)$ & 27.8 (range $24-29)$ & $0.9(0.5)$ & 1 & - \\
\hline Visser (2009) [4] & 108 & $70(7.7)$ & $26.5(2.6)$ & $2.1(0.7)$ & 4 & - \\
\hline
\end{tabular}

Data are mean (SD), unless otherwise specified.

MMSE $=$ Mini-Mental State Examination.

$* 1=\mathrm{A} \beta_{1-42}, 2=$ Total tau, $3=$ Phosphorylated tau, $4=$ Combination of $\mathrm{A} \beta_{1-42}$ with total tau or phosphorylated tau.

Table 2

Effect sizes of biomarkers in CSF or plasma for prediction of Alzheimer's disease in subjects with $\mathrm{MCI}$

\begin{tabular}{lccrr}
\hline & $\begin{array}{c}\text { Number of } \\
\text { studies }\end{array}$ & $\begin{array}{c}\text { Number of subjects } \\
\text { (AD at follow-up/ } \\
\text { no-AD at follow-up) }\end{array}$ & $\begin{array}{c}\text { Cohen's delta } \\
\text { (95\% CI) }\end{array}$ & p-value \\
\hline CSF & 7 & $172 / 252$ & $0.84(0.45-1.24)$ & $<0.001$ \\
$\mathrm{~A} \beta_{1-42}$ & 11 & $238 / 404$ & $0.90(0.62-1.17)$ & $<0.001$ \\
t-tau & 8 & $161 / 316$ & $1.21(0.85-1.57)$ & $<0.001$ \\
p-tau & 4 & $133 / 215$ & $0.18(-0.06-0.41)$ & 0.15 \\
Plasma & 4 & $133 / 215$ & $0.05(-0.24-0.35)$ & 0.72 \\
$\mathrm{~A} \beta_{1-40}$ & 4 & $133 / 215$ & $-0.08(-0.32-0.16)$ & 0.25 \\
$\mathrm{~A} \beta_{1-42}$ & 4 & $79 / 229$ & $0.19(-0.13-0.50)$ & 0.52 \\
Ratio A $\beta_{1-42} / \mathrm{A} \beta_{1-40}$ & & & & \\
Homocysteine & & & & \\
\hline
\end{tabular}

$\mathrm{AD}=$ Alzheimer type dementia; $\mathrm{CSF}=$ cerebrospinal fluid; $\mathrm{A} \beta_{1-42}=$ amyloid- $\beta$ peptide $1-42$;

$\mathrm{A} \beta_{1-40}=$ amyloid $-\beta$ peptide $1-40 ; \mathrm{t}$-tau $=$ total tau; $\mathrm{p}$-tau $=$ phosphorylated tau.

\section{POOLED ANALYSIS OF PREDICTORS FOR AD IN SUBJECTS WITH MCI}

We performed a meta-analysis of markers that had been tested in at least four studies to obtain pooled estimates of the predictive accuracy for progression to AD-type dementia in subjects with MCI. These markers were $\mathrm{A} \beta_{1-42}$, t-tau, and $\mathrm{p}$-tau in CSF and $\mathrm{A} \beta_{1-40}$, $\mathrm{A} \beta_{1-42}$, and homocysteine in plasma.
We identified studies through a systematic search in PubMed, Medline, and Psychinfo (search terms available on request) and from the references of retrieved studies. If multiple studies reported on the same sample, we included the study with the longest follow up or the largest sample size. Data were pooled in a random effects model with STATA (version 9.2; Stata Corp, College Station, TX). For continuous variables, we calculated Cohen's delta as outcome measure [44]. For dichotomized scores, we calculated the sensitivity, speci- 
Table 3

Characteristics of studies included in the meta-analysis of plasma markers in subjects with MCI

\begin{tabular}{lrccc}
\hline Study & $\mathrm{N}$ & Age & MMSE & Follow up (year) \\
\hline$A \beta_{1-42}$ and $A \beta_{1-40}$ & & & & \\
Hansson (2008) [63] & 117 & 69.7 , range 50-85 & $27.0(1.6)$ & 5.2 \\
Hansson (2008) [63] & 110 & 62.9, range 47-79 & $27.0(1.6)$ & Range 2-4 \\
Lopez (2008) [64] & 42 & $79.8(4.3)$ & - & 4.5 \\
$\quad$ Cammarata (2009) [62] & 79 & $75.2(5.2)$ & $>26$ & 2.0 \\
Homocysteine & & & & \\
$\quad$ Maruyama (2004) [55] & 57 & $73.9(5.7)$ & $25.6(1.3)$ & 2.0 \\
Annerbo (2006) [65] & 91 & $65.0(8.5)$ & $26.4(2.6)$ & 6.0 \\
$\quad$ Gabryelewicz (2007) [66] & 105 & $69.3(6.9)$ & $27.3(1.8)$ & 3.0 \\
$\quad$ Siuda (2009) [67] & 55 & $70.8(5.7)$ & - & 1.0 \\
\hline
\end{tabular}

Data are mean (SD), unless otherwise specified.

MMSE $=$ Mini Mental State Examination; $\mathrm{A} \beta_{1-42}=$ amyloid $-\beta$ peptide $1-42 ; \mathrm{A} \beta_{1-40}=$ amyloid- $\beta$ peptide $1-40$.

ficity, positive predictive value, and odds ratio (OR). These dichotomized scores were based on cut-offs provided in the study. If different types of cut-off levels were used within one study, we chose predefined cut-offs over data-driven cut-offs.

\section{$A \beta_{1-42}, t$-tau, and p-tau in CSF}

We identified 19 studies [4,25,45-61] which provided unique data on CSF levels of $\mathrm{A} \beta_{1-42}$, $\mathrm{t}$-tau, and p-tau as predictors for AD-type dementia in subjects with MCI (Table 1). One multi-center study may have included data that had been presented in other studies as well [56], but exclusion of this study did not change the outcome substantially and therefore the study was included in the analyses.

The mean conversion rate to $\mathrm{AD}$-type dementia in the studies was $37 \%$ during a mean follow up of 2.5 years. Cohen's delta showed that $\mathrm{A} \beta_{1-42}$, t-tau, and $\mathrm{p}$-tau were significant predictors of outcome (Table 2). The highest $\mathrm{OR}$ for $\mathrm{AD}$-type dementia was found for the combination of $\mathrm{A} \beta_{1-42}$ and t-tau with or without $\mathrm{p}$-tau (OR 18.1, 95\% confidence interval (CI) 9.6-34.2). An abnormal combination was defined as an abnormal ratio of these markers or as an abnormal score for at least two markers. The combination $\mathrm{A} \beta_{1-42}$ with only p-tau had a slightly lower OR $(17.5,95 \%$ CI 10-30.6). For the individual markers, the OR ranged from $7.54\left(\mathrm{~A} \beta_{1-42}\right)$ to 8.05 (p-tau). For further analysis we selected the combination of $\mathrm{A} \beta_{1-42}$ and t-tau, which was studied in eight studies with a total of 1,236 MCI subjects of which 454 converted to AD-type dementia. The sensitivity of this combination to predict AD-type dementia was 0.87 (95\% CI $0.80-0.95)$, the specificity 0.70 (95\% CI $0.57-0.83)$, and the positive predictive value $0.65(95 \%$ CI 0.53-0.77).

\section{$A \beta_{1-40}$ and $A \beta_{1-42}$ in plasma}

We selected four studies on the association of $\mathrm{A} \beta$ plasma levels with conversion to AD-type dementia in subjects with MCI [62-64] in which a total of 348 subjects with MCI was included (Table 3). The mean conversion rate to AD-type dementia was $38 \%$ during a mean follow up of 3.6 years. The pooled effect sizes for $\mathrm{A} \beta_{1-40}, \mathrm{~A} \beta_{1-42}$, and the ratio $\mathrm{A} \beta_{1-42} / \mathrm{A} \beta_{1-40}$ and conversion to AD-type dementia are shown in Table 2 . None of the effect sizes was statistically significant, although increased levels of $\mathrm{A} \beta_{1-40}$ showed a weak association with conversion to $\mathrm{AD}$-type dementia (Cohen's delta 0.18, $p=0.15$, Table 3, Fig. 2). No dichotomized scores were available.

\section{Homocysteine in plasma}

Four studies [55,65-67] with a total of 308 subjects investigated the predictive value of homocysteine for AD-type dementia in subjects with MCI (Table 3). Mean conversion rate to AD-type dementia was $25 \%$ during a mean follow up of 3.3 years. Homocysteine did not predict AD-type dementia (Cohen's delta 0.19, Table 2). No dichotomized scores were available.

\section{USE OF BIOMARKERS IN SELECTION SUBJECTS FOR DRUG TRIALS}

In the previous section, we showed that the combination of $\mathrm{A} \beta_{1-42}$ and tau in CSF had the best predictive accuracy to predict conversion to AD-type dementia in subjects with MCI. In this section we will investigate how the use of these markers for the selection of subjects can reduce sample size and costs of a trial with a 


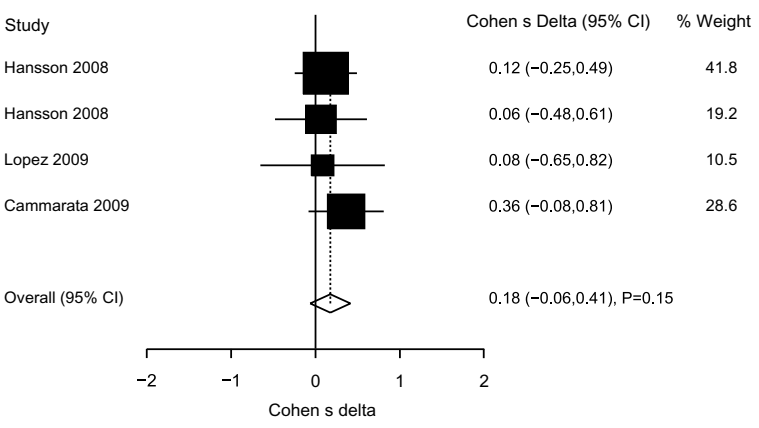

Fig. 2. Pooled Cohen's delta of $\mathrm{A} \beta_{40}$ plasma levels for the prediction of AD-type dementia in subjects with MCI. A positive Cohen's delta indicates that increased plasma levels are associated with an increased risk for $\mathrm{AD}$.

drug that could slow down the progression from MCI to AD-type dementia. We compare the costs of two strategies. The first strategy is a trial in which subjects with MCI are included. The second strategy is a trial in which subjects are enrolled with MCI and an abnormal combination of $\mathrm{A} \beta_{1-42}$ and tau in CSF. Calculations will be performed from the perspective of the performer of the trial and input estimates are mainly based on expert opinion.

The hypothetical trial is a 3-year placebo-controlled trial with $50 \%$ on active treatment to examine the effectiveness of an oral drug on the delay of progression to AD-type dementia in subjects with MCI. Subjects would be selected from a memory clinic setting, with MCI defined as an abnormal performance on neuropsychological tests in the absence of dementia [68]. Costs needed to apply the trial inclusion and exclusion criteria (including cognitive tests and imaging) are estimated on $€ 700$ per patient. Costs for the collection and analysis of CSF are estimated at $€ 324$. The costs of the treatment phase of the trial were estimated to be $€ 5800$ per included patient. This included costs for seven assessments with clinical and cognitive testing and blood analysis and costs related to drugs, drug supply, approval of the medical ethical committee, and subject reimbursement. Costs related to side effects and adverse events were not included in the analysis.

The number of subjects was chosen such that the study could detect a relative decrease of $20 \%$ in conversion rate to $\mathrm{AD}$-type dementia over the 3 -year period, with a power of $90 \%$, a 2-sided alpha of $5 \%$, and a drop-out rate of $30 \%$. The number of subjects to be included would depend on the conversion rate to ADtype dementia in each strategy. Based on the metaanalysis above, we estimated that the 3 -year conversion rate would be $40 \%$ in subjects with MCI and $70 \%$ in subjects with MCI and an abnormal $\mathrm{A} \beta$ and tau in CSF. Based on these conversion rates, the number of subjects to be included in the trial would be 2160 for a study with only subjects with MCI (strategy 1) and 714 for a study with subjects with MCI and an abnormal combination of $\mathrm{A} \beta_{1-42}$ and tau in CSF (strategy 2). Based on a sensitivity of 0.87 and a specificity of 0.70 of the CSF test (see previous section) and a failure rate of lumbar puncture of $10 \%, 1503$ subjects with MCI should undergo lumbar puncture in order to include 714 subjects with an abnormal combination of $\mathrm{A} \beta_{1-42}$ and tau in CSF. The strategies are visualized in Fig. 3. This figure shows the rounded number of subjects for each arm, while costs were calculated based on the unrounded number of subjects.

The trial costs of strategy 1 with only subjects with MCI included would be $€ 14,040,000$ (pre-trial screening costs and trial costs for 2160 subjects, Fig. 3 ). The trial costs of strategy 2 in which subjects with MCI and an abnormal combination of $\mathrm{A} \beta_{1-42}$ and tau in CSF are included would be $€ 5,681,580$ (pre-trial screening costs and CSF collection and analysis costs for 1503 subjects, and trial costs for 714 subjects, Fig. 3). This is a reduction in costs of $60 \%$ compared to strategy 1 .

A one-way sensitivity analysis using the lower bound of the confidence interval of the test-sensitivity $(0.80$ instead of 0.87) mentioned above would increase the number of subjects by 208 and trial costs by $€ 536,194$ (reduction costs compared to strategy 1 of $56 \%$ instead of $60 \%)$. Using the lower bound of the specificity $(0.57$ instead of 0.70 ) would increase the number of subjects by 261 and trial costs by $€ 1,704,852$ (reduction costs compared to strategy 1 of $47 \%$ ). If the lower bound of positive predictive value was used ( 0.58 instead of $0.70), 839$ extra subjects needed to be included and trial costs would increase by $€ 3,171,554$ (reduction costs compared to strategy 1 of $37 \%$ ). A CSF test-price increase of $25 \%$ resulted in an increase of $€ 121,743$ of the total trial costs (reduction costs compared to strategy 1 of $59 \%$ ). If trial costs would double to $€ 11,600$ per patient, strategy 2 would reduce costs by $63 \%$ compared to strategy 1 .

\section{DISCUSSION}

Our main findings are that the combination of $\mathrm{A} \beta_{1-42}$ with total tau in CSF is the best predictor for conversion from MCI to AD-type dementia and that use of these markers in the selection of subjects for trials with drugs that aim to prevent the progression from 


\begin{tabular}{|c|c|c|c|c|c|c|c|}
\hline \multirow[b]{2}{*}{ Strategy 1} & & & $\begin{array}{l}\text { Number } \\
\text { of } \\
\text { subjects }\end{array}$ & Costs in Euro & CSF test & Trial & Total \\
\hline & & & & & & & \\
\hline \multirow{2}{*}{$\begin{array}{l}2160 \text { subjects with } \\
\mathrm{MCl}\end{array}$} & \multicolumn{2}{|l|}{$A D$ at follow-up ( $40 \%)$} & $864^{\#}$ & $€ 700$ & $€ 0$ & $€ 5,800$ & $€ 5,616,000$ \\
\hline & \multicolumn{2}{|l|}{ No $A D$ at follow-up $(60 \%)$} & $1296^{\#}$ & $€ 700$ & $€ 0$ & $€ 5,800$ & $\begin{array}{r}€ 8,424,000 \\
€ 14,040,000\end{array}$ \\
\hline \multirow{6}{*}{$\begin{array}{l}\text { Strategy } 2 \\
1503 \mathrm{MCI} \text { subjects } \\
\text { tested with CSF test }\end{array}$} & AD at follow-up ( $40 \%)$ & Test positive & $471^{\#}$ & $€ 700$ & $€ 324$ & $€ 5,800$ & $€ 3,212,327$ \\
\hline & \multirow{5}{*}{ No $A D$ at follow-up $(60 \%)$} & Test negative & 70 & $€ 700$ & $€ 324$ & & $€ 72,029$ \\
\hline & & Test failed & 60 & $€ 700$ & $€ 324$ & & $€ 61,563$ \\
\hline & & Test positive & $243^{\#}$ & $€ 700$ & $€ 324$ & $€ 5,800$ & $€ 1,661,548$ \\
\hline & & Test negative & 568 & $€ 700$ & $€ 324$ & & $€ 581,769$ \\
\hline & & Test failed & 90 & $€ 700$ & $€ 324$ & & $\begin{array}{r}€ 92,344 \\
€ 5,681,580\end{array}$ \\
\hline
\end{tabular}

Fig. 3. Costs related to different recruitment strategies in a hypothetical trial. Strategy 1 refers to a trial in which subjects with MCI are included and strategy 2 to a trial in which subjects with MCI and an abnormal A $\beta_{1-42} /$ tau ratio in CSF are included. It is assumed that $40 \%$ of the subjects with MCI would convert to AD at follow-up. The number of subjects with a positive and negative test result are based on a sensitivity of 0.87 and a specificity of 0.70 as explained in the text. The rounded number of subjects in each arm is shown, while costs were calculated based on the unrounded numbers of subjects. Test positive $=$ number of subjects with abnormal CSF ratio; test negative = number of subjects with normal $\mathrm{CSF}$ ratio; test failed = number of subjects in which lumber puncture failed (10\% of sample). ${ }^{\#}$ Subjects included in trial.

MCI to AD trials can substantially reduce the sample size and trial costs.

Although a large variety of biomarkers for $\mathrm{AD}$ can quantify dysregulation of $\mathrm{A} \beta$ metabolism or secondary processes in $\mathrm{AD}$ like neurodegeneration, inflammation, oxidative stress, and altered lipid metabolism in CSF and blood, only few of them have been tested as predictor for AD-type dementia in subjects with MCI in more than four independent studies. Among the markers tested in multiple studies, the combination $\mathrm{A} \beta_{1-42}$ with t-tau in CSF had the best predictive accuracy. CSF levels of $\mathrm{A} \beta_{1-42}$, $\mathrm{t}$-tau, and $\mathrm{p}$-tau could also predict conversion to AD-type dementia but the accuracy was lower. Plasma levels of $\mathrm{A} \beta_{1-40}, \mathrm{~A} \beta_{1-42}$, the ratio of $\mathrm{A} \beta_{1-42} / \mathrm{A} \beta_{1-40}$, and homocysteine levels did not predict AD-type dementia.

In our hypothetical trial on the prevention of progression from MCI to AD-type dementia, use of $\mathrm{A} \beta_{1-42}$ and tau in CSF for the selection of subjects could reduce trial costs up to $60 \%$ relative to a trial that would include subjects with MCI that were not selected by CSF markers. This reduction largely resulted from the fact that fewer subjects were needed to be enrolled in order to obtain the required statistical power. The sample size could be smaller because the conversion rate in subjects with MCI and abnormal $\mathrm{A} \beta_{1-42}$ and tau levels (70\%) was much higher compared to that in unselected subjects with MCI (40\%). The sensitivity analysis confirmed the strong effect of conversion rate on costs, as the cost reduction of a model with a conversion rate of $58 \%$ in subjects with abnormal $\mathrm{A} \beta_{1-42}$ and tau levels would be much lower (37\%). The sensitivity analyses also showed that the costs of the CSF test had only a minor influence on the cost reduction and that benefits would be larger if the costs for conducting the trial increased.

Our study has several limitations. We may have overestimated the predictive accuracy of the CSF markers as some studies included in the meta-analysis dichotomized scores according to the best cut off in their study. There were differences in study design between the pooled studies but it was outside the scope of the present paper to explore the effect of this variability on the predictive accuracy. Our meta-analysis was based on relatively few studies, which reduced the accuracy of the parameter estimates. Therefore, we used lower bound estimates in the sensitivity analyses of the cost calculations. Still, these were one-way sensitivity analyses and not full sensitivity analyses. Our costcalculation did not take into account costs associated with side effects of lumbar puncture. The most common side effect is post-lumbar headache in less than $3 \%$ of the subjects, which occasionally needs intervention [69].

We calculated the effect on costs when CSF markers were used to select subjects for treatment trials. However, when CSF markers are used to select subjects for treatment outside the clinical trial setting, the cost- 
benefit could be markedly different. In that case, costs need to be calculated from a societal perspective, which includes all costs and effects related to the disease, such as medication use, caregiver time, patient and caregiver quality of life and institutionalization. The cost reduction of the use of CSF tests in the selection of subjects for treatment in such a setting is likely to be much lower as subjects with a false-negative diagnosis or subjects that could not undergo the diagnostic test would not receive treatment and could not benefit from the reduction in societal costs associated with treatment.

\section{Clinical implications}

Our findings suggest that the design of trials on the prevention of progression from MCI to AD-type dementia could have a higher cost-benefit ratio if subjects are included based on abnormal CSF markers. A possible disadvantage of the use of CSF markers, however, is that the logistics of such trial could become more complex. CSF collection may not be available in all settings and subjects may refuse to undergo lumbar puncture or have a contraindication for it. In addition, facilities should be set-up for central analysis of CSF samples, which can provide a standardized cut-off [70]. If lumbar puncture is performed on a large scale, rare side effects may become apparent.

\section{Future perspectives}

Since lumbar puncture is relatively invasive, a plasma biomarker for $\mathrm{AD}$ would be more attractive. So far attempts to develop an accurate plasma AD marker have been unsuccessful. It seems unlikely that new biomarkers in either CSF or blood may reach or improve the diagnostic accuracy of that of $\mathrm{A} \beta_{1-42}$ and tau in CSF in the near future. New markers that have been tested in subjects with AD-type dementia versus healthy control have generally yielded a lower diagnostic accuracy compared to $\mathrm{A} \beta_{1-42}$ and tau in CSF. A promising alternative may be the combination of different plasma or CSF markers or gene expression profiles, but so far replication of such multiparameter approaches has been difficult [43]. Development of diagnostic markers from proof of concept to large-scale application may take up to 15 years, as was the case for $\mathrm{A} \beta_{1-42}$ and tau in CSF. Future studies should compare the use of CSF makers in trials with that of other diagnostic modalities such as PET or MRI imaging. Finally, it should be investigated whether biomarkers could increase the cost-benefit ratio in the selection of subjects in prevention trials in subjects without MCI or outside a clinical setting, in which the conversion rate to AD-type dementia is much lower.

\section{ACKNOWLEDGMENTS}

The study was in part funded by the European Commission within the 6th framework programme (LSHB2007-037670, PJV) and 7th framework programme (KBBE-2007-211676, IR), and the Centre for Translational Molecular Medicine (www.ctmm.nl), project LeARN, grant 02N-01 (SV and RH). PJV has received in kind or financial support for a research collaboration with Diagenic ASA, Oslo, Norway, and Innogenetics NV, Gent Belgium, both companies that develop diagnostic tests for AD.

Authors' disclosures available online (http://www.jalz.com/disclosures/view.php?id=330).

\section{AUTHOR CONTRIBUTIONS}

IR drafted the introduction and biomarker overview and analysed and reported data on the meta-analysis of plasma markers. SV analysed and reported data on the meta-analysis of CSF markers. RH performed and reported on the cost-benefit analysis. PJV designed the study and drafted the discussion. All authors reviewed the manuscript.

\section{REFERENCES}

[1] Petersen RC, Doody R, Kurz A, Mohs RC, Morris JC, Rabins PV, Ritchie K, Rossor M, Thal L, Winblad B (2001) Current Concepts in Mild Cognitive Impairment. Arch Neurol 58, 1985-1992.

[2] Visser PJ, Verhey FR (2008) Mild cognitive impairment as predictor for Alzheimer's disease in clinical practice: effect of age and diagnostic criteria. Psychol Med 38, 113-122.

[3] Dubois B, Feldman HH, Jacova C, DeKosky ST, BarbergerGateau P, Cummings J, Delacourte A, Galasko D, Gauthier S, Jicha G, Meguro K, O’Brien J, Pasquier F, Robert P, Rossor M, Salloway S, Stern Y, Visser PJ, Scheltens P (2007) Research criteria for the diagnosis of Alzheimer's disease: revising the NINCDS-ADRDA criteria. Lancet Neurol 6, 734-746.

[4] Visser PJ, Verhey F, Knol DL, Scheltens P, Wahlund LO, Freund-Levi Y, Tsolaki M, Minthon L, Wallin A, Hampel H, Bürger K, Pirttila T, Soininen H, Rikkert MO, Verbeek MM, Spiru L, Blennow K (2009) Prevalence and prognostic value of CSF markers of Alzheimer's disease pathology in patients with subjective cognitive impairment or mild cognitive impairment in the DESCRIPA study: a prospective cohort study. Lancet Neurol 8, 619-627.

[5] Consensus report of the Working Group on: "Molecular and Biochemical Markers of Alzheimer's Disease". The Ronald and Nancy Reagan Research Institute of the Alzheimer's Association and the National Institute on Aging Working Group (1998) Neurobiol Aging 19, 109-116.

[6] Hardy J, Selkoe DJ (2002) The amyloid hypothesis of Alzheimer's disease: progress and problems on the road to therapeutics. Science 297, 353-356. 
[7] Walsh DM, Selkoe DJ (2007) A beta oligomers - a decade of discovery. J Neurochem 101, 1172-1184.

[8] Blennow K, Hampel H (2003) CSF markers for incipient Alzheimer's disease. Lancet Neurol 2, 605-613.

[9] Funke SA, Birkmann E, Henke F, Gortz P, Lange-Asschenfeldt C, Riesner D, Willbold D (2007) Single particle detection of Abeta aggregates associated with Alzheimer's disease. Biochem Biophys Res Commun 364, 902-907.

[10] Portelius E, Westman-Brinkmalm A, Zetterberg H, Blennow K (2006) Determination of beta-amyloid peptide signatures in cerebrospinal fluid using immunoprecipitation-mass spectrometry. J Proteome Res 5, 1010-1016.

[11] Tapiola T, Alafuzoff I, Herukka SK, Parkkinen L, Hartikainen P, Soininen H, Pirttila T (2009) Cerebrospinal fluid betaamyloid 42 and tau proteins as biomarkers of Alzheimer-type pathologic changes in the brain. Arch Neurol 66, 382-389.

[12] Hoglund K, Hansson O, Buchhave P, Zetterberg H, Lewczuk P, Londos E, Blennow K, Minthon L, Wiltfang J (2008) Prediction of Alzheimer's disease using a cerebrospinal fluid pattern of C-terminally truncated beta-amyloid peptides. Neurodegener Dis 5, 268-276.

[13] Zetterberg H, Andreasson U, Hansson O, Wu G, Sankaranarayanan S, Andersson ME, Buchhave P, Londos E, Umek RM, Minthon L, Simon AJ, Blennow K (2008) Elevated cerebrospinal fluid BACE1 activity in incipient Alzheimer disease. Arch Neurol 65, 1102-1107.

[14] Maruyama M, Higuchi M, Takaki Y, Matsuba Y, Tanji H, Nemoto M, Tomita N, Matsui T, Iwata N, Mizukami H, Muramatsu S, Ozawa K, Saido TC, Arai H, Sasaki H (2005) Cerebrospinal fluid neprilysin is reduced in prodromal Alzheimer's disease. Ann Neurol 57, 832-842.

[15] Verwey NA, Schuitemaker A, van der Flier WM, Mulder SD, Mulder C, Hack CE, Scheltens P, Blankenstein MA, Veerhuis R (2008) Serum amyloid p component as a biomarker in mild cognitive impairment and Alzheimer's disease. Dement Geriatr Cogn Disord 26, 522-527.

[16] Fagan AM, Mintun MA, Mach RH, Lee SY, Dence CS, Shah AR, LaRossa GN, Spinner ML, Klunk WE, Mathis CA, DeKosky ST, Morris JC, Holtzman DM (2006) Inverse relation between in vivo amyloid imaging load and cerebrospinal fluid Abeta42 in humans. Ann Neurol 59, 512-519.

[17] Freeman SH, Raju S, Hyman BT, Frosch MP, Irizarry MC (2007) Plasma Abeta levels do not reflect brain Abeta levels. J Neuropathol Exp Neurol 66, 264-271.

[18] Borroni B, Colciaghi F, Caltagirone C, Rozzini L, Broglio L, Cattabeni F, Di LM, Padovani A (2003) Platelet amyloid precursor protein abnormalities in mild cognitive impairment predict conversion to dementia of Alzheimer type: a 2-year follow-up study. Arch Neurol 60, 1740-1744

[19] Buerger K, Ewers M, Pirttila T, Zinkowski R, Alafuzoff I, Teipel SJ, DeBernardis J, Kerkman D, McCulloch C, Soininen H, Hampel H (2006) CSF phosphorylated tau protein correlates with neocortical neurofibrillary pathology in Alzheimer's disease. Brain 129, 3035-3041.

[20] Blennow K (2004) Cerebrospinal fluid protein biomarkers for Alzheimer's disease. NeuroRx 1, 213-225.

[21] Britschgi M, Wyss-Coray T (2007) Systemic and acquired immune responses in Alzheimer's disease. Int Rev Neurobiol 82, 205-233.

[22] Craig-Schapiro R, Fagan AM, Holtzman DM (2009) Biomarkers of Alzheimer's disease. Neurobiol Dis 35, 128-140.

[23] Song F, Poljak A, Smythe GA, Sachdev P (2009) Plasma biomarkers for mild cognitive impairment and Alzheimer's disease. Brain Res Rev 61, 69-80.
[24] Teunissen CE, de VJ, Steinbusch HW, De BC (2002) Biochemical markers related to Alzheimer's dementia in serum and cerebrospinal fluid. Neurobiol Aging 23, 485-508.

[25] Tarkowski E, Andreasen N, Tarkowski A, Blennow K (2003) Intrathecal inflammation precedes development of Alzheimer's disease. J Neurol Neurosurg Psychiatry 74, 12001205.

[26] Buchhave P, Janciauskiene S, Zetterberg H, Blennow K, Minthon L, Hansson O (2009) Elevated plasma levels of soluble CD40 in incipient Alzheimer's disease 2. Neurosci Lett 450, 56-59.

[27] Buchhave P, Zetterberg H, Blennow K, Minthon L, Janciauskiene S, Hansson O (2008) Soluble TNF receptors are associated with Abeta metabolism and conversion to dementia in subjects with mild cognitive impairment. Neurobiol Aging, in press.

28] Galimberti D, Schoonenboom N, Scheltens P, Fenoglio C, Bouwman F, Venturelli E, Guidi I, Blankenstein MA, Bresolin $\mathrm{N}$, Scarpini E (2006) Intrathecal chemokine synthesis in mild cognitive impairment and Alzheimer disease. Arch Neurol 63, 538-543.

[29] Mangialasche F, Polidori MC, Monastero R, Ercolani S, Camarda C, Cecchetti R, Mecocci P (2009) Biomarkers of oxidative and nitrosative damage in Alzheimer's disease and mild cognitive impairment. Ageing Res Rev 8, 285-305.

[30] de Leon MJ, Mosconi L, Li J, De SS, Yao Y, Tsui WH, Pirraglia E, Rich K, Javier E, Brys M, Glodzik L, Switalski R, Saint Louis LA, Pratico D (2007) Longitudinal CSF isoprostane and MRI atrophy in the progression to AD. J Neurol 254, 16661675 .

[31] Solfrizzi V, D'Introno A, Colacicco AM, Capurso C, Todarello O, Pellicani V, Capurso SA, Pietrarossa G, Santamato V, Capurso A, Panza F (2006) Circulating biomarkers of cognitive decline and dementia. Clin Chim Acta 364, 91-112.

[32] Bretillon L, Siden A, Wahlund LO, Lutjohann D, Minthon L, Crisby M, Hillert J, Groth CG, Diczfalusy U, Bjorkhem I (2000) Plasma levels of 24S-hydroxycholesterol in patients with neurological diseases. Neurosci Lett 293, 87-90.

[33] Leoni V, Shafaati M, Salomon A, Kivipelto M, Bjorkhem I, Wahlund LO (2006) Are the CSF levels of 24Shydroxycholesterol a sensitive biomarker for mild cognitive impairment? Neurosci Lett 397, 83-87.

[34] Papassotiropoulos A, Lutjohann D, Bagli M, Locatelli S, Jessen F, Buschfort R, Ptok U, Bjorkhem I, von BK, Heun R (2002) 24S-hydroxycholesterol in cerebrospinal fluid is elevated in early stages of dementia. J Psychiatr Res 36, 27-32.

[35] Schonknecht P, Lutjohann D, Pantel J, Bardenheuer H, Hartmann T, von BK, Beyreuther K, Schroder J (2002) Cerebrospinal fluid 24S-hydroxycholesterol is increased in patients with Alzheimer's disease compared to healthy controls. $\mathrm{Neu}$ rosci Lett 324, 83-85.

[36] Han X, Fagan AM, Cheng H, Morris JC, Xiong C, Holtzman DM (2003) Cerebrospinal fluid sulfatide is decreased in subjects with incipient dementia. Ann Neurol 54, 115-119.

[37] Seshadri S (2006) Elevated plasma homocysteine levels: risk factor or risk marker for the development of dementia and Alzheimer's disease? J Alzheimers Dis 9, 393-398.

[38] Ravaglia G, Forti P, Maioli F, Martelli M, Servadei L, Brunetti N, Porcellini E, Licastro F (2005) Homocysteine and folate as risk factors for dementia and Alzheimer disease. Am J Clin Nutr 82, 636-643.

[39] Seshadri S, Beiser A, Selhub J, Jacques PF, Rosenberg IH, D'Agostino RB, Wilson PW, Wolf PA (2002) Plasma homo- 
cysteine as a risk factor for dementia and Alzheimer's disease. $N$ Engl J Med 346, 476-483.

[40] Reitz C, Tang MX, Miller J, Green R, Luchsinger JA (2009) Plasma homocysteine and risk of mild cognitive impairment. Dement Geriatr Cogn Disord 27, 11-17.

[41] Simonsen AH, McGuire J, Hansson O, Zetterberg H, Podust VN, Davies HA, Waldemar G, Minthon L, Blennow K (2007) Novel panel of cerebrospinal fluid biomarkers for the prediction of progression to Alzheimer dementia in patients with mild cognitive impairment. Arch Neurol 64, 366-370.

[42] Ray S, Britschgi M, Herbert C, Takeda-Uchimura Y, Boxer A, Blennow K, Friedman LF, Galasko DR, Jutel M, Karydas A, Kaye JA, Leszek J, Miller BL, Minthon L, Quinn JF, Rabinovici GD, Robinson WH, Sabbagh MN, So YT, Sparks DL, Tabaton M, Tinklenberg J, Yesavage JA, Tibshirani R, Wyss-Coray $\mathrm{T}$ (2007) Classification and prediction of clinical Alzheimer's diagnosis based on plasma signaling proteins. Nat Med 13, 1359-1362.

[43] Soares HD, Chen Y, Sabbagh M, Rohrer A, Schrijvers E, Breteler M (2009) Identifying early markers of Alzheimer's disease using quantitative multiplex proteomic immunoassay panels. Ann N Y Acad Sci 1180, 56-67.

[44] Cohen J (1992) A power primer. Psychological Bulletin 112, 155-159.

[45] Blom ES, Giedraitis V, Zetterberg H, Fukumoto H, Blennow K, Hyman BT, Irizarry MC, Wahlund LO, Lannfelt L, Ingelsson M (2009) Rapid progression from mild cognitive impairment to Alzheimer's disease in subjects with elevated levels of tau in cerebrospinal fluid and the APOE epsilon4/epsilon4 genotype. Dement Geriatr Cogn Disord 27, 458-464.

[46] Brys M, Pirraglia E, Rich K, Rolstad S, Mosconi L, Switalski R, Glodzik-Sobanska L, De SS, Zinkowski R, Mehta P, Pratico D, Saint Louis LA, Wallin A, Blennow K, de Leon MJ (2009) Prediction and longitudinal study of CSF biomarkers in mild cognitive impairment. Neurobiol Aging 30, 682-690.

[47] Ewers MP, Buerger KM, Teipel SJM, Scheltens PM, Schroder JM, Zinkowski RPP, Bouwman FHM, Schonknecht PM, Schoonenboom NSMM, Andreasen NM, Wallin AM, DeBernardis JFP, Kerkman DJP, Heindl BM, Blennow KM, Hampel HMDM (2007) Multicenter assessment of CSFphosphorylated tau for the prediction of conversion of MCI. Neurology 69, 2205-2212.

[48] Fellgiebel A, Scheurich A, Bartenstein P, Müller MJ (2007) FDG-PET and CSF phospho-tau for prediction of cognitive decline in mild cognitive impairment. Psychiatry Research: Neuroimaging 155, 167-171.

[49] Forsberg A, Engler H, Almkvist O, Blomquist G, Hagman GË, Wall A, Ringheim A, Langström B, Nordberg A (2008) PET imaging of amyloid deposition in patients with mild cognitive impairment. Neurobiol Aging 29, 1456-1465.

[50] Hampel H, Teipel SJ, Fuchsberger T, Andreasen N, Wiltfang J, Otto M, Shen Y, Dodel R, Du Y, Farlow M, Moller HJ, Blennow K, Buerger K (2003) Value of CSF [beta]-amyloid142 and tau as predictors of Alzheimer's disease in patients with mild cognitive impairment. Molecular Psychiatry 9, 705-710.

[51] Hansson O, Zetterberg H, Buchhave P, Andreasson U, Londos E, Minthon L, Blennow K (2007) Prediction of Alzheimer's Disease Using the CSF A $\beta 42 / \mathrm{A} \beta 40$ Ratio in Patients with Mild Cognitive Impairment. Dement Geriatr Cogn Disord 23, 316-320.

[52] Hansson O, Zetterberg H, Buchhave P, Londos E, Blennow K, Minthon L (2006) Association between CSF biomarkers and incipient Alzheimer's disease in patients with mild cognitive impairment: a follow-up study. Lancet Neurol 5, 228-234.
[53] Herukka SK, Hallikainen MMDP, Soininen HMDP, Pirttila TMDP (2005) CSF A[beta]42 and tau or phosphorylated tau and prediction of progressive mild cognitive impairment. $\mathrm{Neu}$ rology 64, 1294-1297.

[54] Kester MI, Verwey NA, van Elk EJ, Blankenstein MA, Scheltens P, van der Flier WM (2009) Progression from MCI to AD: Predictive value of CSF A[beta]42 is modified by APOE genotype. Neurobiol Aging, in press.

[55] Maruyama M, Matsui T, Tanji H, Nemoto M, Tomita N, Ootsuki M, Arai H, Sasaki H (2004) Cerebrospinal fluid tau protein and periventricular white matter lesions in patients with mild cognitive impairment: implications for 2 major pathways. Arch Neurol 61, 716-720.

[56] Mattsson N, Zetterberg H, Hansson O, Andreasen N, Parnetti L, Jonsson M, Herukka SK, van der Flier WM, Blankenstein MA, Ewers M, Rich K, Kaiser E, Verbeek M, Tsolaki M, Mulugeta E, Rosen E, Aarsland D, Visser PJ, Schroder J, Marcusson J, de Leon M, Hampel H, Scheltens P, Pirttila T, Wallin A, Jonhagen ME, Minthon L, Winblad B, Blennow K (2009) CSF biomarkers and incipient Alzheimer disease in patients with mild cognitive impairment. JAMA 302, 385-393.

[57] Papaliagkas VT, Anogianakis G, Tsolaki MN, Koliakos G, Kimiskidis VK (2009) Progression of Mild Cognitive Impairment to Alzheimer's Disease: Improved Diagnostic Value of the Combined Use of N200 Latency and $\beta$-Amyloid(1-42) Levels. Dement Geriatr Cogn Disord 28, 30-35.

[58] Parnetti L, Lanari A, Silvestrelli G, Saggese E, Reboldi P (2006) Diagnosing prodromal Alzheimer's disease: Role of CSF biochemical markers. Mech Ageing Dev 127, 129-132.

[59] Riemenschneider M, Lautenschlager N, Wagenpfeil S, Diehl J, Drzezga A, Kurz A (2002) Cerebrospinal fluid tau and \{beta $\}$ amyloid 42 proteins identify Alzheimer disease in subjects with mild cognitive impairment. Arch Neurol 59, 1729-1734.

[60] Schonknecht P, Pantel J, Kaiser E, Thomann P, Schröder J (2007) Increased tau protein differentiates mild cognitive impairment from geriatric depression and predicts conversion to dementia. Neurosci Lett 416, 39-42.

[61] Zetterberg H, Wahlund LO, Blennow K (2003) Cerebrospinal fluid markers for prediction of Alzheimer's disease. Neurosci Lett 352, 67-69.

[62] Cammarata S, Borghi R, Giliberto L, Pardini M, Pollero V, Novello C, Fornaro M, Vitali A, Bracco L, Caltagirone C, Bossu P, Odetti P, Tabaton M (2009) Amyloid-beta42 plasma levels are elevated in amnestic mild cognitive impairment. $J$ Alzheimers Dis 18, 267-271.

[63] Hansson O, Zetterberg H, Vanmechelen E, Vanderstichele H, Andreasson U, Londos E, Wallin A, Minthon L, Blennow K (2008) Evaluation of plasma Abeta(40) and Abeta(42) as predictors of conversion to Alzheimer's disease in patients with mild cognitive impairment. Neurobiol Aging 31, 357-367.

[64] Lopez OL, Kuller LH, Mehta PD, Becker JT, Gach HM, Sweet RA, Chang YF, Tracy R, DeKosky ST (2008) Plasma amyloid levels and the risk of AD in normal subjects in the Cardiovascular Health Study. Neurology 70, 1664-1671.

[65] Annerbo S, Wahlund LO, Lokk J (2006) The significance of thyroid-stimulating hormone and homocysteine in the development of Alzheimer's disease in mild cognitive impairment: a 6-year follow-up study. Am J Alzheimers Dis Other Demen 21, 182-188.

[66] Gabryelewicz T, Styczynska M, Luczywek E, Barczak A, Pfeffer A, Androsiuk W, Chodakowska-Zebrowska M, Wasiak B, Peplonska B, Barcikowska M (2007) The rate of conversion of mild cognitive impairment to dementia: predictive role of depression. Int J Geriatr Psychiatry 22, 563-567. 
[67] Siuda J, Gorzkowska A, Patalong-Ogiewa M, Krzystanek E, Czech E, Wiechula B, Ganczorz W, Danch A, JasinskaMyga B, Opala G (2009) From mild cognitive impairment to Alzheimer's disease - influence of homocysteine, vitamin B12 and folate on cognition over time: results from one-year follow-up. Neurol Neurochir Pol 43, 321-329.

[68] Petersen RC, Doody R, Kurz A, Mohs RC, Morris JC, Rabins PV, Ritchie K, Rossor M, Thal L, Winblad B (2001) Current Concepts in Mild Cognitive Impairment 17. Arch Neurol 58, 1985-1992.

[69] Blennow K, Wallin A, Hager O (1993) Low frequency of post- lumbar puncture headache in demented patients. Acta Neurol Scand 88, 221-223.

[70] Verwey NA, van der Flier WM, Blennow K, Clark C, Sokolow S, De Deyn PP, Galasko D, Hampel H, Hartmann T, Kapaki E, Lannfelt L, Mehta PD, Parnetti L, Petzold A, Pirttila T, Saleh L, Skinningsrud A, Swieten JC, Verbeek MM, Wiltfang J, Younkin S, Scheltens P, Blankenstein MA (2009) A worldwide multicentre comparison of assays for cerebrospinal fluid biomarkers in Alzheimer's disease. Ann Clin Biochem 46, 235-240 